日本植物病理学会報 74 巻 3 号掲載「平成 20 年度日本植物病理学会大会講演要旨」において、発表者名順に重大な

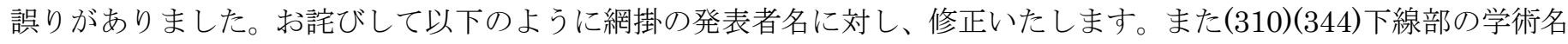
を併せて訂正いたします。

\section{【誤】日植病報 74-3 号掲載分}

\section{p. 168}

(7) 多賀正節・有本英里香・金子真美 日本産ジャガイモ疫病菌 の倍数性解析 Taga, M., Arimoto, E. and Kaneko, M.: Ploidy Analysis of Japanese Isolates of Phytophthora infestans.

\section{p.169}

(10) 有江 力・關波直子・寺岡 徹 Gibberella fujikuroi フェ ロモンレセプター遺伝子破壊株の交配能と病原性 Arie, T., Sekinami, N. and Teraoka, T.: Mating Ability and Pathogenicity of Disruptants of Pheromone Receptor Genes in Gibberella fujikuroi.

p. 174

(30) 穴戸雅宏・津久井理恵 マルチプレックス PCR とリアルタ イム PCR を用いたメロンホモプシス根腐病菌および黒点根腐病 菌の検出と定量 Shishido, M. and Tsukui, R.: Detection and Quantification of Phomopsis sclerotioides and/or Monosporascus cannonballus Using Multiplex PCR and Real-Time PCR.

p. 178

（44）古屋廣光 - 幸坂知春 - 藤 晋一 - 戸田 武 - 景山幸二 水 田土壤から分離されたPythium spp.の同定並びにイネ苗に対する 病原性 Furuya, H., Kohsaka, C., Fuji, S., Toda, T. and Kageyama, K.: Identification of Pythium spp. Isolated from Rice Paddy Fields and Their Pathogenicity to Rice Seedlings.

p. 179

(47) 山岡直人 ・ 西村優博 ・ 西口正通・松本 勲 オオムギうど んこ病菌 (Blumeria graminis) の Life Cycle における宿主表面 クチクラの役割り Yamaoka, N., Nishimura, M., Nishiguchi, M. and Matsumoto, I.: The Role of the Cuticle of Host Surface in the Life Cycle of Blumeria graminis.

p. 193

(101) 新城 亮・荒木祐子・有江 力・寺岡 徹 イネいもち病 菌感染イネにおけるマンノース結合型イネレクチン (MRL) の発 現量とその局在性 Shinjo, A., Araki, Y., Arie, T. and Teraoka, T.: The Expression Level and Localization of Mannose-binding Rice Lectin (MRL) in Rice Plant Infected with Rice Blast Fungus, Magnaporthe grisea.

p. 195

(108) 高野義孝 ・ 小野澤真理子 $・$ Volker Lipka ・島田智弓 $・$ 奥野 哲郎・Paul Schulze-Lefert シロイヌナズナの非宿主抵抗性にお ける PEN2 の要求性は, 炭疽病菌の侵入様式に影響をうける Takano, Y., Onozawa, M., Lipka, V., Shimada, C., Okuno, T. and Schulze-Lefert, P.: Requirement of PEN2 for Nonhost Resistance in Arabidopsis thaliana Is Affected by Invasion Manners of Anthracnose Fungi.

p. 199

(121) Md. Khurshed Alam Bhuiyan - Shaikh Sharmin Siddique Physiological and Pathological Studies of Fusarium oxysporum f. sp. phaseoli Infecting Bush Bean.

p. 200

（128）豊田和弘・川西由利子・松崎成剛・稲垣善茂・一瀨勇規 ・ 白石友紀 Medicago truncatula におけるサプレッサー応答性遺 伝子 Toyoda, K., Kawanishi, Y., Matsuzaki, M., Inagaki, Y., Ichinose, Y. and Shiraishi, T.: Genes Expressed in Leaves of Medicago truncatula in Response to Fungal Suppressor from Mycosphaerella pinodes.

p. 201

(131) 辻 元人 - 寺田 寛・森 あい. 田中茂幸・久保康之 $ア$ ブラナ科野菜類炭疽病菌の $\operatorname{chs} s d 1$ 破壊株は物理的侵入力を有す るがシロイヌナズナ Col-0 への病原性は低下する Tsuji, G., Terada, H., Mori, A., Tanaka, S. and Kubo, Y.: chssd1 Mutant of Colletotrichum higginsianum Retains Ability for Physical Penetration, but Becomes Impaired its Pathogenicity for Arabidopsis thaliana Col-0.

\section{【正】改訂版}

（7）有本英里香・金子真美・多賀正節 日本産ジャガイモ疫病菌 の倍数性解析 Arimoto, E., Kaneko, M. and Taga, M.: Ploidy Analysis of Japanese Isolates of Phytophthora infestans.

（10）關波直子・寺岡 徹・有江 力 Gibberella fujikuro フェ ロモンレセプター遺伝子破壊株の交配能と病原性 Sekinami, N., Teraoka, T. and Arie, T.: Mating Ability and Pathogenicity of Disruptants of Pheromone Receptor Genes in Gibberella fujikuroi.

（30）津久井理恵・宍戸雅宏 マルチプレックス PCR とリアルタ イム PCR 用いたメロンホモプシス根腐病菌および黒点根腐病菌 の検出と定量 Tsukui, R. and Shishido, M.: Detection and Quantification of Phomopsis sclerotioides and/or Monosporascus cannonballus Using Multiplex PCR and Real-Time PCR.

（44）幸坂知春 - 藤 晋一 - 戸田 武 - 景山幸二 ・古屋廣光 水 田土壤から分離された Pythium spp.の同定並びにイネ苗に対する 病原性 Kohsaka, C., Fuji, S., Toda, T., Kageyama, K. and Furuya, H.: Identification of Pythium spp. Isolated from Rice Paddy Fields and Their Pathogenicity to Rice Seedlings.

(47) 西村優博・西口正通・松本 勲・山岡直人 オオムギうど んこ病菌 (Blumeria graminis) の Life Cycle における宿主表面ク チクラの役割り Nishimura, M., Nishiguchi, M., Matsumoto, I. and Yamaoka, N.: The Role of the Cuticle of Host Surface in the Life Cycle of Blumeria graminis.

（101）荒木祐子・新城 亮・有江 力・寺岡 徹 イネいもち病 菌感染イネにおけるマンノース結合型イネレクチン (MRL) の発 現量とその局在性 Araki, Y., Shinjo, A., Arie, T. and Teraoka, T.: The Expression Level and Localization of Mannose-binding Rice Lectin (MRL) in Rice Plant Infected with Rice Blast Fungus, Magnaporthe grisea.

（108）小野澤真理子 ・ Volker Lipka ・島田智弓 ・ 奥野哲郎 ・ Paul Schulze-Lefert・高野義孝 シロイヌナズナの非宿主抵抗性におけ る PEN2 の要求性は, 炭疽病菌の侵入様式に影響をうける Onozawa, M., Lipka, V., Shimada, C., Okuno, T., Schulze-Lefert, P. and Takano, Y: Requirement of PEN2 for Nonhost Resistance in Arabidopsis thaliana Is Affected by Invasion Manners of Anthracnose Fungi.

(121) Shaikh Sharmin Siddique Md. Khurshed Alam Bhuiyan Physiological and Pathological Studies of Fusarium oxysporum f. sp. phaseoli Infecting Bush Bean.

（128）川西由利子・松崎成剛・稲垣善茂・一瀬勇規・豊田和弘・ 白石友紀 Medicago truncatula におけるサプレッサー応答性遺 伝子 Kawanishi, Y., Matsuzaki, M., Inagaki, Y., Ichinose, Y., Toyoda, K. and Shiraishi, T. Genes Expressed in Leaves of Medicago truncatula in Response to Fungal Suppressor from Mycosphaerella pinodes.

（131）寺田 寛・森 あい・田中茂幸・辻 元人 ・ 久保康之 ブラナ科野菜類炭疽病菌の $\operatorname{chssd} 1$ 破壊株は物理的侵入力を有する がシロイヌナズナ Col-0 への病原性は低下寸る Terada, H., Mori, A., Tanaka, S., Tsuji, G. and Kubo, Y.: chssd1 Mutant of Colletotrichum higginsianum Retains Ability for Physical Penetration, but Becomes Impaired its Pathogenicity for Arabidopsis thaliana $\mathrm{Col}-0$. 


\section{p. 203}

（139）中嶋祐一・七里和俊・鎌倉高志 イネいもち病菌における 予想 GPI アンカー型タンパク質をコードする $M G A L 1$ の付着器形 成における役割 Nakajima, Y., Shichiri, K. and Kamakura, T. Role of $M G A L 1$, Encoding a Putative GPI-anchored Protein of Magnaporthe oryzae, in the Appressorium Formation.

p. 205

（145）中屋敷均・笠原誠司・Quoc, N.B. ・ 土佐幸雄・眞山滋志 RNA サイレンシング法によるイネ科植物いもち病菌の GATA, bHLH 転写因子ファミリーの機能解析 Nakayashiki, H., Kasahara, S., Quoc, N. B., Tosa, Y. and Mayama, S.: Functional Analysis of GATA and bHLH Transcription Factors in Magnaporthe oryzae by an RNA Silencing-based Approach.

p. 208

（156）平八重一之・芦澤武人・森脇丈治・高橋真実 マルチライ ン用葉いもち病勢進展シミュレーションモデル BLASTMUL への 突然変異パラメータの導入 Hirayae, K., Ashizawa, T., Moriwaki, J. and Takahashi, M.: Introducing the Mutation Rate from Avirulence to Virulence into BLASTMUL, a Leaf Blast Model in Rice Multilines.

p. 211

（167）東條元昭・美濃健一・沼田州平・星野 保・貴田健一 ב ムギとオーチャードグラスの褐色雪腐病に関与する Pythium 属菌 の北海道における分布 Tojo, M., Mino, K., Numata, S., Hoshino, T. and Kida, K.: Distribution of Pythium spp. Causing Snow Rot on Wheat and Orchard Grass in Hokkaido.

\section{p. 218}

（194）岡崎真一郎 ・ 山崎修一 ・古田明子 - 久野公子 ・行徳 裕 奥田 充 Cucurbit chlorotic yellows virus（仮称）の宿主範囲 Okazaki, S., Yamasaki, S., Furuta, A., Kuno, K., Gyoutoku, Y. and Okuda, M.: The Host Range of Cucurbit Chlorotic Yellows Virus.

p. 222

(207) 小出理恵 - 長嶋一郎・T.O. Dizon ・ 夏秋啓子 Banana bunchy top virus (BBTV) の代替宿主の探索 Koide, R., Nagashima, I., Dizon, T.O. and Natsuaki, K.T.: Alternative Hosts of Banana bunchy top virus.

p. 224

(215) Natsuaki, K.T., Chikh Ali, M. and Maoka, T. The Characterization of Cucumber mosaic virus and its Satellite RNA from Potato in Syria.

\section{p. 231}

（242）竹下 稔 - 野口眞季子 - 石川（末廣）典子・夏秋知英 ・増 田 税・大島一里・古屋成人・土屋健一 $2 \mathrm{~b}$ 遺伝子を欠乏したキ ユウモザイクウイルス (CMV) とカブモザイクウイルス (TuMV)

の Nicotiana benthamiana における挙動 Takeshita, M., Noguchi, M., Ishikawa-Suehiro, N., Natsuaki, T., Masuta, C., Ohshima, K., Furuya, N. and Tsuchiya, K.: Dynamic Study of 2b-Deleted Mutant of Cucumber mosaic virus and Turnip mosaic vitus in Nicotiana benthamiana.

\section{p. 232}

(245) 小倉里江子 - 中浜克彦 - 松尾直子 - 平塚和之 各種 Potyvirus 属ウイルス由来 5’非翻訳領域（5'UTR）の翻訳エンハン サー活性ならびに Internal ribosome entry site (IRES) 活性につ いて Ogura, R., Nakahama, K., Matsuo, N. and Hiratsuka, K. Translational Enhancer and Internal Ribosome Entry Site (IRES) Activities from the 5'Untranslated Region (5'UTR) of Potyviruses.

p. 237

(264) Eusebio-Cope, A., Faruk, M.I. and Suzuki, N. A Host Factor, NAM-1, Involved in Hypovirus Symptom Expression in the Chestnut Blight Fungus, Cryphonectria parasitica.

\section{p. 239}

（273）夏秋知英・馬場一樹 - 久野修司 - 三好 洋 ・王 蔚芹 - 小 堀崇・西川尚志・奥田誠一・小坂能尚 ズッキー二黄斑モザイク ウイルス弱毒株の HC-Pro の機能解析 Natsuaki, T., Baba, K., Kuno, S., Miyoshi, H., Wang, W-Q., Kobori, T., Nishigawa, H., Okuda, S. and Kosaka, Y.: Analyses of HC-Pro Protein of Attenuated Zucchini yellow mosaic virus Isolates.
（139）七里和俊・中嶋祐一・鎌倉高志 イネいもち病菌における 予想 GPI アンカー型タンパク質をコードする $M G A L 1$ の付着器形 成における役割 Shichiri, K., Nakajima, Y. and Kamakura, T. Role of $M G A L 1$, Encoding a Putative GPI-anchored Protein of Magnaporthe oryzae, in the Appressorium Formation.

（145）笠原誠司・Quoc, N.B. ・土佐幸雄・眞山滋志・中屋敷均 RNA サイレンシング法によるイネ科植物いもち病菌の GATA, bHLH 転写因子ファミリーの機能解析 Kasahara, S., Quoc, N. B., Tosa, Y., Mayama, S. and Nakayashiki, H.: Functional Analysis of GATA and bHLH Transcription Factors in Magnaporthe oryzae by an RNA Silencing-based Approach.

（156）芦澤武人・平八重一之・森脇丈治・高橋真実 マルチライ ン用葉いもち病勢進展シミュレーションモデル BLASTMUL への 突然変異パラメータの導入 Ashizawa，T., Hirayae，K., Moriwaki, J. and Takahashi, M.: Introducing the Mutation Rate from Avirulence to Virulence into BLASTMUL, a Leaf Blast Model in Rice Multilines.

（167）美濃健一・東條元昭・沼田州平・星野 保・貴田健一 コ ムギとオーチャードグラスの褐色雪腐病に関与寸る Pythium 属菌 の北海道における分布 Mino, K., Tojo, M., Numata, S., Hoshino, T. and Kida, K.: Distribution of Pythium spp. Causing Snow Rot on Wheat and Orchard Grass in Hokkaido.

（194）山崎修一 ・岡崎真一郎 - 古田明子 - 久野公子 - 行徳 裕 奥田 充 Cucurbit chlorotic yellows virus（仮称）の宿主範囲 Yamasaki, S., Okazaki, S., Furuta, A., Kuno, K., Gyoutoku, Y. and Okuda, M.: The Host Range of Cucurbit Chlorotic Yellows Virus.

（207）長嶋一郎・小出理恵・T.O. Dizon ・夏秋啓子 Banana bunchy top virus (BBTV) の代替宿主の探索 Nagashima, I., Koide, R., Dizon, T.O. and Natsuaki, K.T.: Alternative Hosts of Banana bunchy top virus.

(215) Chikh Ali, M., Maoka, T. and Natsuaki, K.T. The Characterization of Cucumber mosaic virus and its Satellite RNA from Potato in Syria.

（242）野口眞季子 - 竹下 稔 - 石川（末廣）典子・夏秋知英・増 田 税・大島一里・古屋成人・土屋健一 $2 \mathrm{~b}$ 遺伝子を欠乏したキ ユウモザイクウイルス（CMV）とカブモザイクウイルス（TuMV) の Nicotiana benthamiana における挙動 Noguchi, M., Takeshita, M., Ishikawa-Suehiro, N., Natsuaki, T., Masuta, C., Ohshima, K., Furuya, N. and Tsuchiya, K.: Dynamic Study of 2b-Deleted Mutant of Cucumber mosaic virus and Turnip mosaic vitus in Nicotiana benthamiana.

(245) 中浜克彦・小倉里江子・松尾直子・平塚和之 各種 Potyvirus 属ウイルス由来 5’非翻訳領域（5'UTR）の翻訳エンハンサー活性 ならびに Internal ribosome entry site (IRES) 活性について Nakahama, K., Ogura, R., Matsuo, N. and Hiratsuka, K. Translational Enhancer and Internal Ribosome Entry Site (IRES) Activities from the 5'Untranslated Region (5'UTR) of Potyviruses.

(264) Faruk, M.I., Eusebio-Cope, A. and Suzuki, N. A Host Factor, NAM-1, Involved in Hypovirus Symptom Expression in the Chestnut Blight Fungus, Cryphonectria parasitica.

（273）馬場一樹 - 久野修司 - 三好 洋 - 王 蔚芹・小堀 崇・西 川尚志・奥田誠一・小坂能尚・夏秋知英 ズッキー二黄斑モザイ クウイルス弱毒株の HC-Pro の機能解析 Baba, K., Kuno, S., Miyoshi, H., Wang, W-Q., Kobori, T., Nishigawa, H., Okuda, S., Kosaka, Y. and Natsuaki, T.: Analyses of HC-Pro Protein of Attenuated Zucchini yellow mosaic virus Isolates. 


\section{p. 240}

（276）海道真典・築野靖子 • 三瀬和之・奥野哲郎 Red clover necrotic mosaic virus RNAの複製は移行タンパク質の細胞内局在 性に影響する Kaido, M., Tsuno, Y., Mise, K. and Okuno, T. Replication of Red clover necrotic mosaic virus RNA Affects Subcellular Localization of the Movement Protein.

\section{p. 243}

（288）中原健二・井門由佳理・厚見 剛・上田一郎 シロクロー バモザイクウイルスベクターによる RNA サイレンシングの誘導 Nakahara, K., Ido, Y., Atsumi, G. and Uyeda, I.: White clover mosaic virus Induced RNA Silencing.

\section{p. 244}

(289) Nishiguchi, M., Haque, N.A.K.M. and Yamaoka, N. Spreading of RNA Silencing and Transgene Methylation Analysis of Transgenic Nicotiana benthamiana with the Coat Protein Gene of $S$ weet potato feathery mottle virus.

\section{p. 245}

（294）田村顕裕・須貝友和・磯貝雅道・高橋英樹・吉川信幸 リ ンゴ小球形潜在ウイルスベクターを利用したシロイヌナズナのウ イルス抵抗性遺伝子（RCY1）のウイルス誘導ジーンサイレンシン グ (VIGS) Tamura, A., Sugai, T., Isogai, M., Takahashi, H. and Yoshikawa, N.: Virus-induced Gene Silencing of RCY1 Gene in Arabidopsis thaliana using Apple latent spherical virus.

\section{p. 248}

（307）一瀬勇規 - 内藤佳奈 ・田口富美子 ・ 鈴木智子 ・ 稲垣善茂 豊田和弘・白石友紀 タバコ野火病菌ベん毛タンパク質フラジェ リンの防御応答誘導活性とべん毛機能の解析 Ichinose, Y. Naito, K., Taguchi, F., Suzuki, T., Inagaki, Y., Toyoda, K. and Shiraishi, T.: Functional Analysis of Flagellar Motility and Elicitor Activity of Flagellin in Pseudomonas syringae pv. tabaci.

\section{p. 249}

（310）松倉 藍・関谷敏芳・平田久笑・露無慎二 カンキツかい よう病菌によるかいよう形成におけるカンキッ TERT (Telomerase reverse transcriptase)遺伝子の役割 Matsukura, A., Sekiya, T., Hirata, H. and Tsuyumu, S.: A Role of Citrus TERT ( Telomerase reverse transcriptase ) Gene on Canker Formation Caused by Xanthomoans axonopodis pv. citri.

p. 252

（322）清水慶明 $\cdot$ 上松 寛・塚本貴敬・水野明文・佐藤成良・齊 藤範彦 Rhodococcus fasciansによるペチュニア帯化病（新称）

Shimizu, Y., Uematsu, H., Tsukamoto, T., Mizuno, A., Sato, S. and Saito, N.: Bacterial Fasciation of Petunia Caused by Rhodococcus fascians.

\section{p. 255}

（330）瀧川雄一・辻本明佳・楠元智子 ・ 川田宏史 ・ 山本圭祐・小 林真樹・牧野孝宏・中田孝之 各種植物から分離された Acidovorax valerianellae の研究 Takikawa, Y., Tsujimoto, H., Kusumoto, S., Kawada, H., Yamamoto, K., Kobayashi, M., Makino, T. and Nakata, T.: A Comparative Study of Acidovorax valerianellae Strains Isolated from Various Hosts.

\section{p. 258}

(341) 武田佑輔・長谷徳次・平田久笑・露無慎二 カンキツかい よう病菌検出のための発光遺伝子群 $\operatorname{lux} A B$ 融合ファージの作出 Takeda, Y., Hase, T., Hirata, H. and Tsuyumu, S.: Isolation of Bacteriophage Fused with Luminescence Gene Cassette for Detection of Xanthomonas axonopodis pv. citri.

（344）奥 尚・世良友美・宮本あゆみ・三宅隆史・田中浩司 広 島県に発生するイネ白葉枯病菌の病原性レースならびにそれらの 遺伝的多様性 Oku, T., Sera, T., Miyamoto, A., Miyake, T. and Tanaka, K.: Pathogenic Races of Xanthonoas oryzae pv. oryzae Found in Hiroshima Prefecture and Its Genetic Diversity.

p. 259

（348）田村勝徳・塩澤美紀・高師義幸 シロイヌナズナ BLADE ON PETIOLE 2 の病害抵抗性における機能解析 Tamura, K., Shiozawa, M. and Takashi, Y.: Functional Analysis of Arabidopsis BLADE ON PETIOLE 2 in Disease Resistance.
（276）築野靖子・三瀬和之・奥野哲郎・海道真典 Red clover necrotic mosaic virus RNA の複製は移行タンパク質の細胞内局在 性に影響する Tsuno, Y., Mise, K., Okuno, T. and Kaido, M. Replication of Red clover necrotic mosaic virus RNA Affects Subcellular Localization of the Movement Protein.

（288）井門由佳理・厚見 剛・中原健二・上田一郎 シロクロー バモザイクウイルスベクターによる RNA サイレンシングの誘導 Ido, Y., Atsumi, G., Nakahara, K. and Uyeda, I.: White clover mosaic virus Induced RNA Silencing.

(289) Haque, N.A.K.M., Yamaoka, N. and Nishiguchi, M. Spreading of RNA Silencing and Transgene Methylation: Analysis of Transgenic Nicotiana benthamiana with the Coat Protein Gene of $S$ weet potato feathery mottle virus.

（294）須貝友和・田村顕裕・磯貝雅道・高橋英樹・吉川信幸 リ ンゴ小球形潜在ウイルスベクターを利用したシロイヌナズナのウ イルス抵抗性遺伝子（RCY1）のウイルス誘導ジーンサイレンシン グ (VIGS) Sugai, T., Tamura, A., Isogai, M., Takahashi, H. and Yoshikawa, N.: Virus-induced Gene Silencing of RCY1 Gene in Arabidopsis thaliana using Apple latent spherical virus.

（307）内藤佳奈・田口富美子・鈴木智子・稲垣善茂・豊田和弘・ 白石友紀・一瀬勇規 タバコ野火病菌べん毛タンパク質フラジェ リンの防御応答誘導活性とべん毛機能の解析 Naito, K. Taguchi, F., Suzuki, T., Inagaki, Y., Toyoda, K., Shiraishi, T. and Ichinose, Y: Functional Analysis of Flagellar Motility and Elicitor Activity of Flagellin in Pseudomonas syringae pv. tabaci.

（310）関谷敏芳・松倉 藍・平田久笑・露無慎二 カンキツかい よう病菌によるかいよう形成におけるカンキッ TERT (Telomerase reverse transcriptase)遺伝子の役割 Sekiya, T., Matsukura, A., Hirata, H. and Tsuyumu, S.: A Role of Citrus TERT ( Telomerase reverse transcriptase ) Gene on Canker Formation Caused by Xanthomonas axonopodis pv. citri.

（322）上松 寛 $\cdot$ 清水慶明・塚本貴敬 - 水野明文・佐藤成良・齊 藤範彦 Rhodococcus fascians によるぺチュニア帯化病（新称） Uematsu, H., Shimizu, Y., Tsukamoto, T., Mizuno, A., Sato, S and Saito, N.: Bacterial Fasciation of Petunia Caused by Rhodococcus fascians.

（330）辻本明佳 ・楠元智子 $\cdot$ 川田宏史 $\cdot$ 山本圭祐・小林真樹 ・ 牧 野孝宏・中田孝之・瀧川雄一 各種植物から分離された Acidovorax valerianellae の研究 Tsujimoto, H., Kusumoto, S., Kawada, H., Yamamoto, K., Kobayashi, M., Makino, T., Nakata, T. and Takikawa, Y.: A Comparative Study of Acidovorax valerianellae Strains Isolated from Various Hosts.

(341) 長谷徳次・武田佑輔・平田久笑・露無慎二 カンキツかい よう病菌検出のための発光遺伝子群 $\operatorname{lux} A B$ 融合ファージの作出 Hase, T., Takeda, Y., Hirata, H. and Tsuyumu, S.: Isolation of Bacteriophage Fused with Luminescence Gene Cassette for Detection of Xanthomonas axonopodis pv. citri.

（344）世良友美・宮本あゆみ・三宅隆史・田中浩司・奥 尚 広 島県に発生するイネ白葉枯病菌の病原性レースならびにそれらの 遺伝的多様性 Sera, T., Miyamoto, A., Miyake, T., Tanaka, K. and $\mathrm{Oku}, \mathrm{T}$ : Pathogenic Races of Xanthomonas oryzae pv. oryzae Found in Hiroshima Prefecture and Its Genetic Diversity.

（348）塩澤美紀・高師義幸・田村勝徳 シロイヌナズナ BLADE ON PETIOLE 2 の病害抵抗性における機能解析 Shiozawa, M., Takashi, Y. and Tamura, K.: Functional Analysis of Arabidopsis BLADE ON PETIOLE 2 in Disease Resistance. 


\section{p. 260}

（349）上運天博・坂巻幾子 ビワがんしゅ病細菌の病原性遺伝子 pSVA の $\mathrm{N}$ 末端側領域の機能解析 Kamiunten, H. and Sakamaki, I.: Genetic Analysis of the N-terminal Region of the Virulence Gene psvA Isolated from Pseudomonas syringae pv. eriobotryae.

(350) 梅川沙希子・川島沙由梨 ・平田久笑・露無慎二 Xanthomonas axonopodis pv. citriのかいよう形成因子 APl1 の転 写後修飾 Umekawa, S., Kawashima, S., Hirata, H. and Tsuyumu, S.: Biochemical Analyses of Apl1, Cankerforming Factor of Xanthomonas axonopodis pv. citri.

p. 261

(355) 井上 望・藤澤侑弥・佐々木則英・平田久笑・露無慎二 Pectobacterium carotovorum subsp. carotovorum のフラジェリ ンにおける細胞死誘導必須領域の決定 Inoue, N., Fujisawa, Y., Sasaki, N., Hirata, H. and Tsuyumu, S.: Determination of Domain in Flagellin of Pectobacterium carotovorum subsp. carotovorum for Induction of Cell Death.

p. 265

（370）大藤泰雄・緒方達志 - 小堀陽一 ・河邊邦正 - 米本仁巳 $・$ Nguyen Thanh Binh・Nguyen Minh Chau グリーニング病がカ ンキツの初期生育における地上部の生長と光合成速度および台木 根の生長と呼吸に及ぼす影響 Ohto, Y., Ogata, T., Kobori, Y., Kawabe, K., Yonemoto, H., Nguyen, T.B. and Nguyen, M.C. The Effects of Greening Disease on the Growth and Photosynthetic Rate of Citrus Seedlings and the Development and Respiration of Root in their Rootstocks.

\section{p. 272}

(396) 上中弘典・西本奈未・高林賢吾 - 西出圭太 ・櫻井寿美子 田中 淨・Jeffery L. Dangl シロイヌナズナの過敏感細胞死の誘 導機構におけるオーキシン応答性転写抑制因子 Aux/IAAの機能解 析 Kaminaka, H., Nishimoto, N., Takabayashi, K., Nishide, K., Sakurai, S., Tanaka, K. and Dangl, J.L.: Functional Analysis of Auxin-Responsive Transcriptional Repressor Aux/IAAs on the Induction Mechanism of Hypersensitive Cell Death in Arabidopsis thaliana.

p. 273

(399) 長谷 修 • 河村陽子 - 久保田真弓 - 一瀬勇規 - 竹中重仁 . 高橋英樹 生物防除微生物 Pythium oligandrumによる誘導抵抗 性における $S G T 1 ， R A R 1$ 及び $N P R 1$ の関与 Hase，S., Kawamura, Y., Kubota, M., Ichinose, Y., Takenaka, S. and Takahashi, H.: Involvement of SGR1, RAR1 and NPR1 in Induced Resistance by Pythium oligandrum.

p. 274

（401）犬飼 剛 - 金 甫珢・増田 税・松浦英幸・高橋英樹 力 ブモザイクウイルスに感染したアラビドプシスにおけるえそ誘導 機構 Inukai, T., Kim, B., Masuta, C., Matsuura, H. and Takahashi, H.: Induction Mechanism for the Necrosis on Arabidopsis thaliana by Turnip mosaic virus Infection.

\section{p. 275}

（404）平塚和之・笹野佳奈子・盤指 豪・浦田信明・小倉里江子 · 田中恒之・小野祥子 発光レポーターを用いた抵抗性誘導剤スク リーニング手法の改良 Hiratsuka, K., Sasano, K., Banzashi, G., Urata, N., Ogura, R., Tanaka, T. and Ono, S.: Improvement of Screening Method for Plant Activators by Bioluminescence Reporter System.

p. 277

(412) 高橋智子 - 井上裕貴 $\cdot$ 辻 元人 ・ 梅村賢司 $\cdot$ 三冨正明 $\cdot$ 小 坂能尚 - 津田和久 - 久保康之 乳酸菌 Pediococcu pentosaceus KMC05 株を処理したシロイヌナズナにおける遺伝子発現変動の 解析 Takahashi, T., Inoue, Y., Tsuji, G., Umemura, K., Mitomi, M., Kosaka, Y., Tsuda, K. and Kubo, Y.: Analysis of Altered Gene Expression in Arabidopsis thaliana Treated with Lactic Acid Bacteria Pediococcus pentosaceus KMC05.
（349）坂巻幾子・上運天博 ビワがんしゅ病細菌の病原性遺伝子 psvA の $\mathrm{N}$ 末端側領域の機能解析 Sakamaki, I. and Kamiunten, H.: Genetic Analysis of the N-terminal Region of the Virulence Gene $p_{S v} A$ Isolated from Pseudomonas syringae pv. eriobotryae.

（350）川島沙由梨・梅川沙希子・平田久笑 - 露無慎二 Xanthomonas axonopodis pv. citriのかいよう形成因子 APl1 の転 写後修飾 Kawashima, S., Umekawa, S., Hirata, H. and Tsuyumu, S.: Biochemical Analyses of Apl1, Cankerforming Factor of Xanthomonas axonopodis pv. citri.

（355）藤澤侑弥・井上 望・佐々木則英・平田久笑・露無慎二 Pectobacterium carotovorum subsp. carotovorum のフラジェリ ンにおける細胞死誘導必須領域の決定 Fujisawa, Y., Inoue, N., Sasaki, N., Hirata, H. and Tsuyumu, S.: Determination of Domain in Flagellin of Pectobacterium carotovorum subsp. carotovorum for Induction of Cell Death.

（370）緒方達志 - 小堀陽一 - 河邊邦正 $\cdot$ 米本仁巳 - 大藤泰雄 Nguyen Thanh Binh・Nguyen Minh Chau グリーニング病がカ ンキツの初期生育における地上部の生長と光合成速度および台木 根の生長と呼吸に及ぼす影響 Ogata, T., Kobori, Y., Kawabe, K. Yonemoto, H., Ohto, Y., Nguyen, T.B. and Nguyen, M.C.: The Effects of Greening Disease on the Growth and Photosynthetic Rate of Citrus Seedlings and the Development and Respiration of Root in their Rootstocks.

(396) 西本奈未・高林賢吾・西出圭太・櫻井寿美子・田中淨・Jeffery L. Dangl ・ 上中弘典 シロイヌナズナの過敏感細胞死の誘導機構 におけるオーキシン応答性転写抑制因子 Aux/IAA の機能解析 Nishimoto, N., Takabayashi, K., Nishide, K., Sakurai, S., Tanaka, K., Dangl, J.L. and Kaminaka, H: Functional Analysis of Auxin-Responsive Transcriptional Repressor Aux/IAAs on the Induction Mechanism of Hypersensitive Cell Death in Arabidopsis thaliana.

（399）河村陽子 - 長谷 修 - 久保田真弓 - 一瀬勇規 - 竹中重仁 • 高橋英樹 生物防除微生物 Pythium oligandrum による誘導抵抗 性における $S G T 1, R A R 1$ 及び $N P R 1$ の関与 Kawamura, Y. Hase, S., Kubota, M., Ichinose, Y., Takenaka, S. and Takahashi, H.: Involvement of SGR1, $R A R 1$ and $N P R 1$ in Induced Resistance by Pythium oligandrum.

（401）金 甫珉・増田 税 - 松浦英幸 - 高橋英樹 - 犬飼 剛 力 ブモザイクウイルスに感染したアラビドプシスにおけるえそ誘導 機構 Kim, B., Masuta, C., Matsuura, H., Takahashi, H. and Inukai, T: Induction Mechanism for the Necrosis on Arabidopsis thaliana by Turnip mosaic virus Infection.

（404）笹野佳奈子・盤指 豪・浦田信明・小倉里江子・田中恒之・ 小野祥子・平塚和之 発光レポーターを用いた抵抗性誘導剂スク リーニング手法の改良 Sasano, K., Banzashi, G., Urata, N., Ogura, R., Tanaka, T., Ono, S. and Hiratsuka, K. Improvement of Screening Method for Plant Activators by Bioluminescence Reporter System.

(412) 井上裕貴 $\cdot$ 高橋智子 $\cdot$ 辻 元人 $\cdot$ 梅村賢司 $\cdot$ 三冨正明 - 小 坂能尚 - 津田和久 - 久保康之 乳酸菌 Pediococcu pentosaceus KMC05 株を処理したシロイヌナズナにおける遺伝子発現変動の 解析 Inoue, Y., Takahashi, T., Tsuji, G., Umemura, K., Mitomi, M., Kosaka, Y., Tsuda, K. and Kubo, Y.: Analysis of Altered Gene Expression in Arabidopsis thaliana Treated with Lactic Acid Bacteria Pediococcus pentosaceus KMC05. 